\title{
Development of a New Technique to Produce Winter Cherimoyas
}

\author{
Laura Soler and Julián Cuevas ${ }^{1}$
}

AdDitional Index wORDs. Annona cherimola, flowering promotion, defoliation, harvest date modification, out-of-season fruit production, fruit quality

Summary. This paper describes a novel technique to produce cherimoya (Annona cherimola) fruit during the winter season. In a controlled experiment the trees were encouraged to flower out of season by pruning them back severely in January, followed by tipping the newly emerged shoots together with the removal of apical leaves on either 1 or 15 June. Both dates were highly successful because all tipped shoots produce a second bloom in July. On average, four flowers per shoot were produced in the new growth in response to defoliation treatments. The second blooming lasted no more than 2 weeks. Late-forming flowers were hand pollinated and gave rise to fruit of high quality about $50 \mathrm{~d}$ later than an ordinary crop. A yield of $13 \mathrm{t} \cdot \mathrm{ha}^{-1}$ was produced, with no significant differences between treatments. Postponing hand defoliation by 15 days delayed the harvest period 15 to 20 days, but no other effects on fruit set and quality were noted. Fruit harvested in December and January did not show chilling injury and reached full flavor. Number of seed per fruit, and consequently fruit size, was often increased in out-of-season cherimoyas. Late fruit suffered less preharvest drop than an ordinary crop. This work shows the possibility of producing high-quality cherimoyas during winter when the cherimoya fruit is in great demand.

$\mathrm{C}$ herimoya (Annona cherimola) is a fruit crop indigenous to the Andean valleys on the border between Peru and Ecuador (Popenoe, 1921) of which Spain is the world's largest producer. The main harvest season for cherimoyas in Spain is autumn. The cherimoya is a highly perishable fruit and an oversupply in the market during October and November causes prices to drop dramatically, making it a marginally profitable crop in Spain.

The production of more profitable out-of-season cherimoyas may be possible by modifying the date of budbreak. Cherimoya buds are unusual in that they are grouped in a bud complex under leaf petiole; therefore, leaf fall is a prerequisite for budbreak and bloom. Bloom typically takes place about 2 months after the leaves abscise. Surprisingly, flower initiation occurs very early the previous year. Only 4 weeks after the new leaves have unfolded, the subpetiolar buds initiate flower development

Department of Crop Production, University of Almería, La Cañada de San Urbano, 04120 Almería, Spain

This research was partially supported by the project CO3-106 Consejería de Agricultura y Pesca, Junta de Andalucía and by Carchuna La Palma (SCA).

We are grateful to Fernando Díaz for all his advice and technical assistance.

${ }^{1}$ Corresponding author. E-mail: jcuevas@ual.es.
(Higuchi and Utsunomiya, 1999). Normally, these flowers would blossom the following spring in May and June after natural leaf abscission, which occurs in March and April.

Bud paradormancy imposed by the presence of a leaf was discussed by George and Nissen (1987) 20 years ago when they suggested overcoming it by the removal of leaves. Hand or chemical defoliation can be carried out at different times, shifting the harvest date to a more lucrative period. The removal of senescent leaves weeks before natural abscission moderately advances harvest as a result of earlier blooming (González et al., 2005; Magdahl, 1989). In atemoya $(A$. cherimola $\times A$. squamosa), light tipping combined with the removal of 6 to 10 apical leaves is highly effective in producing late flowering (George and Nissen,
1987). This approach used in cherimoya creates a similar effect. In this species, heavy pruning in spring followed by tipping and hand defoliation in mid summer allows flowers to form in August and September that are then hand pollinated. The fruit produced the following spring are of a high quality (Soler et al., 2002). However, during winter, when demand for cherimoyas is at its height, market supply is limited because only some crop persists in the coolest production districts. Moreover, the quality of the cherimoyas produced in these cool areas is often inadequate-the fruit being small, with low sugar content, and frequently frost damaged. The objective of this paper is to document a reliable new technique for early-season areas based on pruning and leaf removal of new shoots to produce high-quality cherimoyas during the winter.

\section{Materials and methods}

The experiments were carried out during two seasons, 2004-05 and 2005-06, in the coastal area of Granada around Motril (lat. $36^{\circ} 45^{\prime} \mathrm{N}$, long. $3^{\circ} 27^{\prime} \mathrm{W}$ ), in southern Spain. The area has a mild subtropical climate and is renowned for its early harvests in horticulture. The trial was conducted on 8-year-old 'Fino de Jete' trees, open vase trained, and spaced $7 \times 4 \mathrm{~m}$ apart in a loamyclay soil. All the trees were drip irrigated with $\approx 6000 \mathrm{~m}^{3} \cdot \mathrm{ha}^{-1}$ water, and received $150 \mathrm{~kg} \cdot \mathrm{ha}^{-1} \mathrm{~N}$ and $150 \mathrm{~kg} \cdot \mathrm{ha}^{-1} \mathrm{~K}$ as ammonium and potassium nitrate respectively.

The experiment was completely randomized with six replications (trees) per treatment. Three treatments were compared: a control consisting of the standard crop management, and two treatments that

\begin{tabular}{llll}
\hline $\begin{array}{l}\text { Units } \\
\text { To convert U.S. to SI, } \\
\text { multiply by }\end{array}$ & U.S. unit & SI unit & $\begin{array}{l}\text { To convert SI to U.S., } \\
\text { multiply by }\end{array}$ \\
\hline 0.3048 & $\mathrm{ft}$ & $\mathrm{m}$ & 3.2808 \\
0.0700 & $\mathrm{ft}^{3} / \mathrm{acre}$ & $\mathrm{m}^{3} \cdot \mathrm{ha}^{-1}$ & 14.2913 \\
2.54 & $\mathrm{inch}^{-}(\mathrm{es})$ & $\mathrm{cm}$ & 0.3937 \\
6.4516 & inch & $\mathrm{cm}^{2}$ & 0.1550 \\
0.4536 & $\mathrm{lb}$ & $\mathrm{kg}$ & 2.2046 \\
1.1209 & $\mathrm{lb} / \mathrm{acre}$ & $\mathrm{kg} \cdot \mathrm{ha}^{-1}$ & 0.8922 \\
28.3495 & $\mathrm{Oz}$ & $\mathrm{g}$ & 0.0353 \\
28,350 & $\mathrm{Oz}$ & $\mathrm{mg}$ & $3.5274 \times 10-5$ \\
2.2417 & ton $/ \mathrm{acre}$ & $\mathrm{t} \cdot \mathrm{ha}^{-1}$ & 0.4461 \\
$\left({ }^{\circ} \mathrm{F}-32\right) \div 1.8$ & ${ }^{\circ} \mathrm{F}$ & ${ }^{\circ} \mathrm{C}$ & $\left(1.8 \times{ }^{\circ} \mathrm{C}\right)+32$ \\
& & &
\end{tabular}


promoted off-season flowering. The treatments were repeated on the same trees during both seasons.

Control trees $(\mathrm{Tl})$ were pruned in mid April by thinning l-year-old shoots, leaving one shoot intact every $40 \mathrm{~cm}$. Treated trees were pruned in January by removing most 1 -year-old shoots and cutting back the remaining shoots to two to three basal buds to encourage vigorous sprouting (Fig. 1A). On 1 June (T2) or 15 June (T3), 100 of the new shoots formed after the January pruning were randomly selected on each tree. They were tipped by cutting back the last $5 \mathrm{~cm}$ of new growth and the two most apical leaves were removed by hand (Fig. 1B). Leaf removal is essential to stimulate the blossoming of the subpetiolar buds (Fig. 1C).

During bloom, 100 flowers/tree in the first season, and 85 in the second season, were hand pollinated using a pollination puffer (Kurita Tabaco Co., Tochigi, Japan). This was carried out at the commencement of flower anthesis with undiluted pollen collected the previous day from partially open flowers of neighboring 'Fino de Jete' trees. The pollen was stored overnight at room temperature (Richardson and Anderson, 1996; Schroeder, 1941). Exactly the same procedure was used to pollinate the control trees. As no other flowers were hand pollinated in any treatment, yield was mostly limited to that resulting from these flowers. Ten shoots were tagged on each of six trees per treatment to monitor bloom date and number of flowers per bud. Initial fruit set was evaluated $30 \mathrm{~d}$ after pollination on 10 flowers per tree for each hand pollination operation (carried out two to four times per season depending on blooming length and number of flowers available).

Fruit size, yield, productivity, and preharvest drop were recorded at commercial harvest when every single fruit was also weighed for grading based on the official norms for cherimoya (Ministerio de Agricultura Pesca y Alimentación, 1990). Fruit was harvested every $10 \mathrm{~d}$. Fifteen fruit per tree were randomly selected from the most representative sample to determine fruit and skin weight, soluble solids concentration (SSC; measured as a percentage), titratable acidity (measured as milligrams of malic acid per $100 \mathrm{~g}$ fresh pulp weight) (Alique and Zamorano, 2000), and seed index ratio (measured as the number of seeds per $100 \mathrm{~g}$ fresh fruit). Analyses of variance were performed using Statgraphics Plus 4.1 software (Manugistics, Rockville, MD).

\section{Results}

The flowering season in control trees started in early June and full bloom took place around mid June (Fig. 2), when hand pollination was performed. Most flowers in the control trees developed singly or in groups of two to four flowers on 1year-old shoots and at the basal nodes
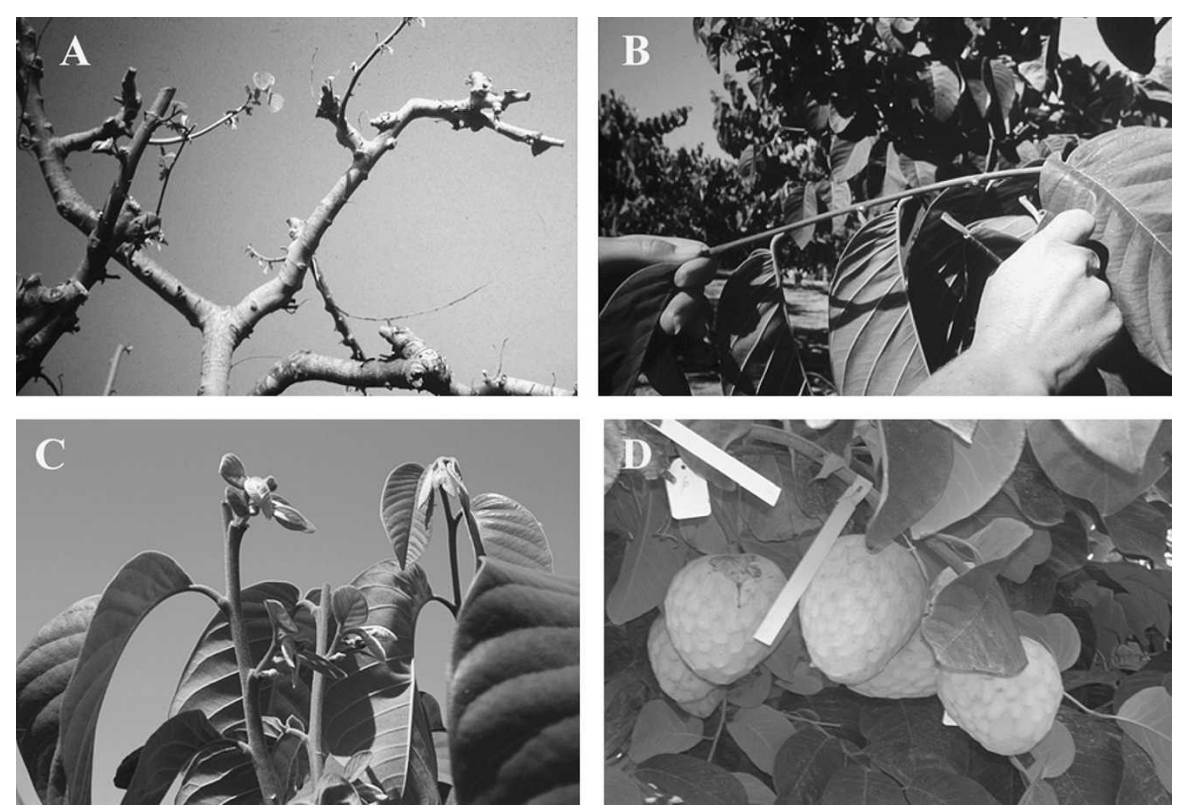

Fig. 1. Steps to produce out-of-season cherimoya fruit. (A) Pruned shoots back to spur. (B) Tipped shoots and leaf removal. (C) New growth and flowering induced on new twigs. (D) Large fruit formed at the shoot apex.

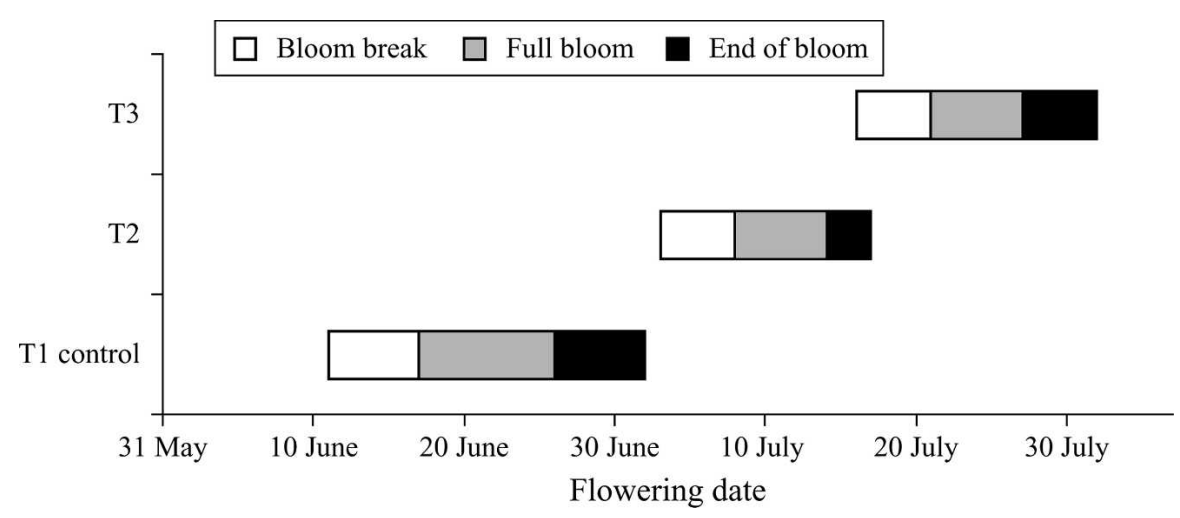

Fig. 2. Flowering course in control and tipped, hand defoliated cherimoya trees during 2004-05 season. Control (T1); tipped and hand defoliated trees on 1 June (T2); tipped and hand defoliated trees on 15 June (T3). 


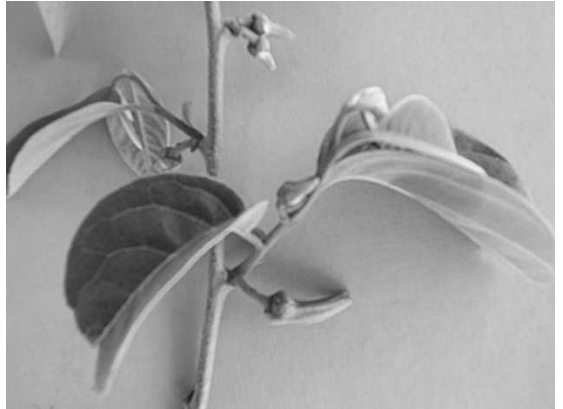

Fig. 3. Cherimoya flowers from floral buds on 1-year-old shoots and from mixed buds arising in the basal nodes of the new growth.

bud were produced on these spurs during this first season. If hand pollinated, these flowers could have produced early-maturing fruit; however, this operation was not undertaken because early fruit production was not the objective of this work. The spurs stopped producing flowers by mid June. However, we were able to induce a second flowering during the same season by tip pruning and leaf removal of the newly formed shoots. These flowers opened in early and mid July for T2 and T3 respectively (Fig. 2). Late flowers were not produced in either the control trees or on shoots left intact in T2 and T3. On the contrary, all shoots tipped and defoliated produced late flowers during both seasons. On average, $4.2 \pm$ 0.2 flowers per shoot were produced during the 2004-05 season in both treatments. During the second season, T2 produced more flowers reaching anthesis than T3 $(5.4 \pm 0.3$ vs. $3.4 \pm 0.4$ flowers $/$ shoot; $P<$ 0.01 ).

Because the number of defoliated shoots in this experiment was limited to 100 shoots/tree, the number of flowers available for hand pollination was reduced in treated trees (a total of between 340 and 540 flowers/tree, depending on the defoliation treatment and season). However, blooming intensity was sufficient to achieve the desired level of fruit production, and also to allow the best flowers to be selected according to their position in the tree canopy. The time required for the flowers to reach full blossom was essentially the same for treatments T2 and T3 during both seasons. That is, $10 \%$ of the flowers had opened their petals about 33 to $34 \mathrm{~d}$ after pruning and defoliation, whereas $90 \%$ of them had finished their cycle $48 \mathrm{~d}$ after leaf removal. The flowering season in treated trees was greatly reduced, lasting no more than 2 weeks. In contrast, the flowering season endured $25 \mathrm{~d}$ in control trees (Fig. 2).

More than $80 \%$ of the handpollinated flowers set fruit, and no significant differences were detected in the percentage of fruit set between treatments or years. During the first season, no differences were found in the number of fruit per tree among treatments (Table 1). Average productivity was $\approx 0.20 \mathrm{~kg} \cdot \mathrm{cm}^{-2}$ of trunk cross-sectional area. Yield was limited to $33 \pm 2 \mathrm{~kg} /$ tree in controls, whereas $\mathrm{T} 2$ and $\mathrm{T} 3$ trees averaged $40 \pm 2$ and $39 \pm 4 \mathrm{~kg} /$ tree respectively. Differences in yield were not significant. During the second season less fruit was produced by T2 and T3 defoliation treatments (Table 1$)$. However, the yields for both T2 and T3 $(33 \pm 2$ $\mathrm{kg} /$ tree) were similar to that achieved in the control $(32 \pm 3 \mathrm{~kg} /$ tree $)$, as the lower number of fruit from T2 and T3 trees was offset by their larger size (Table 2).

This increase in fruit size might explain the improved grading observed in $\mathrm{T} 2$ and $\mathrm{T} 3$ trees during the second season (Fig. 4). However, some improvement in grading also occurred in treated trees during the first season, when there was no difference in fruit number among treatments (Fig. 4). It should be noted that the number of fruit in control trees was higher than the number of hand-pollinated flowers during the second season (Table 1 ). This was the result of the setting of some fruit from open pollination. In some instances, fruit from open and hand pollination were almost indistinguishable, and therefore selective

Table 1. Fruit production and preharvest drop recorded in control (T1) and in tipped and hand defoliated cherimoya trees on 1 June (T2) or on 15 June (T3).

\begin{tabular}{|c|c|c|c|c|c|c|}
\hline \multirow[b]{2}{*}{ Treatments } & \multicolumn{2}{|c|}{$\begin{array}{c}\text { Fruit }^{\mathrm{z}} \\
\text { (no./tree) }\end{array}$} & \multicolumn{2}{|c|}{$\begin{array}{c}\text { Productivity } \\
\left(\mathrm{kg} \cdot \mathrm{cm}^{-2} \text { TCSA }\right)^{y}\end{array}$} & \multicolumn{2}{|c|}{$\begin{array}{l}\text { Preharvest } \\
\text { drop }(\%)^{x}\end{array}$} \\
\hline & 2004 & 2005 & 2004 & 2005 & 2004 & 2005 \\
\hline $\mathrm{Tl}$ (control) & $97 a^{w}$ & $97 \mathrm{a}$ & $0.20 \mathrm{a}$ & $0.19 \mathrm{a}$ & $18 \mathrm{a}$ & $17 \mathrm{a}$ \\
\hline $\mathrm{T} 2$ & $99 a$ & $74 \mathrm{~b}$ & $0.22 \mathrm{a}$ & $0.18 \mathrm{a}$ & $12 \mathrm{ab}$ & $12 \mathrm{a}$ \\
\hline T3 & $99 \mathrm{a}$ & $76 \mathrm{~b}$ & $0.23 \mathrm{a}$ & $0.19 \mathrm{a}$ & $7 \mathrm{~b}$ & $5 \mathrm{~b}$ \\
\hline
\end{tabular}

harvesting was not possible. However, open-pollinated flowers usually produce very small, misshapen fruit. These noncommercial fruit, particularly abundant during the second year on control trees, were not considered in the analyses. Losses resulting from preharvest fruit drop were higher for the control than T2 and T3 (Table 1).

The proportion of edible produce did not vary with the delay in harvesting. Skin represented about $30 \%$ of fruit weight, with similar values for all treatments in both years (Table 2). The number of seeds per fruit and the seed index increased in fruit produced under defoliation treatments in both seasons. Fruit seediness was partially offset by their larger fruit size. Lower, more acceptable values for the seed index were obtained during the second season under all treatments (Table 2). The harvest date was delayed about 5 and 7 weeks for T2 and T3 trees respectively compared with the control trees (Table 3 ). The time required for fruit to reach maturity in the control trees was $135 \mathrm{~d}$, whereas $145 \mathrm{~d}$ were needed between pollination and harvest in T2 and T3 trees. Soluble solids concentration (percent) tended to diminish with a later harvest date (Table 2). Although significant, the differences were slight, and SSC values were within cultivar standards and guaranteed full flavor for lateharvested fruit. No effects of defoliation were detected in fruit acidity (Table 2).

\section{Discussion}

This experiment shows the possibility of extending the cherimoya marketing season into winter by a novel technique that modifies the time of budbreak and bloom. This technique relies on the production of 
Table 2. Fruit quality recorded in control (T1) and in tipped and hand defoliated cherimoya trees on 1 June (T2) or on 15 June (T3).

\begin{tabular}{|c|c|c|c|c|c|c|c|c|c|c|c|c|}
\hline \multirow[b]{2}{*}{ Treatments } & \multicolumn{2}{|c|}{ Fruit wt $(g)^{\mathrm{z}}$} & \multicolumn{2}{|c|}{ Skin wt $(\%)^{y}$} & \multicolumn{2}{|c|}{$\begin{array}{c}\text { Seeds } \\
\text { (no./fruit) }\end{array}$} & \multicolumn{2}{|c|}{ Seed index ${ }^{x}$} & \multicolumn{2}{|c|}{ SSC (\%) } & \multicolumn{2}{|c|}{$\mathrm{TA}^{\mathrm{w}}$} \\
\hline & 2004 & 2005 & 2004 & 2005 & 2004 & 2005 & 2004 & 2005 & 2004 & 2005 & 2004 & 2005 \\
\hline $\mathrm{Tl}$ (control) & $348 \mathrm{a}^{\mathrm{v}}$ & $383 \mathrm{~b}$ & $29 a$ & $26 \mathrm{~b}$ & $64 \mathrm{~b}$ & $49 \mathrm{~b}$ & $18.5 \mathrm{a}$ & $14.2 \mathrm{~b}$ & $23.4 \mathrm{a}$ & $22.4 \mathrm{a}$ & $150 \mathrm{a}$ & 181 \\
\hline $\mathrm{T} 2$ & 393 a & $465 \mathrm{a}$ & $28 \mathrm{a}$ & $27 \mathrm{ab}$ & $79 \mathrm{a}$ & $83 a$ & $20.5 \mathrm{a}$ & $19.2 \mathrm{a}$ & $21.8 \mathrm{~b}$ & $21.4 \mathrm{ab}$ & $138 \mathrm{a}$ & $219 a$ \\
\hline $\mathrm{T} 3$ & $356 \mathrm{a}$ & $449 \mathrm{a}$ & $29 \mathrm{a}$ & $28 \mathrm{a}$ & $75 \mathrm{a}$ & $77 \mathrm{a}$ & $21.5 \mathrm{a}$ & $19.9 \mathrm{a}$ & $21.5 \mathrm{~b}$ & $20.6 \mathrm{~b}$ & $134 \mathrm{a}$ & $211 a$ \\
\hline
\end{tabular}

${ }^{\mathrm{z}} \lg =0.0353 \mathrm{oz}$.

${ }^{y}$ Data were arcsine transformed before analysis of variance. Values reported are based on raw data.

${ }^{x}$ Number of seeds per $100 \mathrm{~g}$ of pulp.

wTitratable acidity (milligrams malic acid per $100 \mathrm{~g}$ pulp fresh weight); $1 \mathrm{mg}=3.5274 \times 10^{-5} \mathrm{oz}$.

"Mean separation in columns by Duncan's multiple range test at $P \leq 0.05$.

Data for each treatment are the mean of 15 fruit per tree and six trees per treatment. SSC, soluble solids concentration.

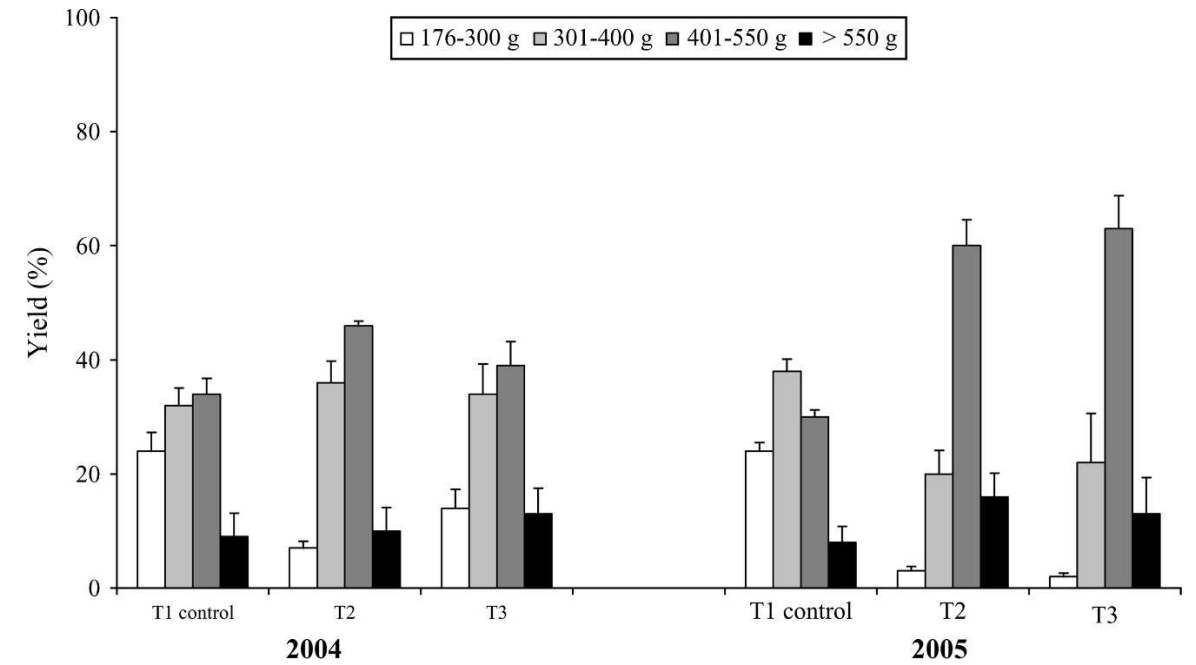

Fig. 4. Fruit size distribution in control and treated cherimoya trees during the 2004-05 and 2005-06 seasons. Grading based on official norms specific to cherimoya (Ministerio de Agricultura Pesca y Alimentación, 1990). 1 g = 0.0353 oz.

Table 3. Modification of the pollination and harvest periods of tipped and hand defoliated cherimoya trees on 1 June (T2) or on 15 June (T3) during the 2004-05 and 2005-06 seasons.

\begin{tabular}{lccccc}
\hline & \multicolumn{2}{c}{ Pollination period } & & \multicolumn{2}{c}{ Harvest period } \\
\cline { 2 - 3 } \cline { 5 - 6 } Treatments & $\mathbf{2 0 0 4}$ & $\mathbf{2 0 0 5}$ & & $\mathbf{2 0 0 4}$ & $\mathbf{2 0 0 5}$ \\
\hline T1 $($ control $)$ & 11-30 June & 14-22 June & & 25 Oct.-28 Nov. & 26 Oct.-28 Nov. \\
T2 & 6-12 July & 8-19 July & & 28 Nov.-21 Dec. & 3 Dec.-10 Jan. \\
T3 & 20-27 July & 20-26 July & & 15 Dec.-17 Jan. & 16 Dec.-31 Jan. \\
\hline
\end{tabular}

out-of-season flowers by tipping new tender shoots, combined with the removal of terminal leaves. Heavy pruning is also required to promote vigorous growth able to support the large fruit produced (Fig. 1D). A high proportion of the flowers produced on the new shoots set fruit that was of high quality in terms of size, sweetness, and flavor (Table 2). Despite harvesting in December and January, fruit also showed a complete absence of chilling injury. Average temperature in the area during December and January was 13.0 and $10.6{ }^{\circ} \mathrm{C}$ in 2004 and 12.6 and $10.6{ }^{\circ} \mathrm{C}$ in 2005. The minimum temperature never fell below $4{ }^{\circ} \mathrm{C}$ during in either harvest season. Nevertheless, this technique seems more suitable for warm winter areas not prone to frost.

The main objection to the quality of winter cherimoyas is an elevated seed index. In this experiment the number of seeds per fruit and the seed index increased under both defoliation treatments during both seasons. This probably reflects more efficient ovule fertilization with the warmer temperatures of July. Although the higher seediness in treated trees was partially offset by a larger fruit size, a lower seed index is commercially desirable. Pollen dilution is therefore suggested with this technique. Nonetheless, it should be noted that the seed index was also high for control trees in both seasons when compared with the value of 12 considered standard for this cultivar (Guirado et al., 2004). Source limitation resulting from the heavy pruning performed seems the most likely reason behind the incapacity of the tree to enlarge these seedy fruit further. Therefore, the reduction of tree canopy achieved by pruning should be taken into account when deciding on the number of flowers to be hand pollinated.

Care should also be taken when using this new approach because of the limited number of flowers produced and the short time available for artificial pollination: scarcely 3 weeks. Additional measures must be implemented to avoid pollen shortage for hand pollination operations during these months when no other source of pollen is available. On the other hand, the lower number of flowers and their dependence on hand pollination reduces the number of fruit produced from open-pollinated flowers. Open pollination is commonly undesirable in most producing areas because it leads to small, misshapen, noncommercial cherimoyas that have to be removed or left unharvested.

Quick, regular, and uniform sprouting of cherimoya buds in response to hand defoliation allows programming the date of intervention to find the most convenient periods for marketing. With this approach, the time from budbreak 
to blossoming and from blossoming to harvest has to be considered. Flower development from budbreak to anthesis consistently took about 5 weeks in both early and late defoliation in both seasons. Thirty-one days are needed for the same process in New Delhi, India, under standard management (Thakur and Singh, 1965). Time required for fruit to reach maturity depends on the flowering period. Fruit ripening in autumn needs 4.5 months from blossoming to harvest. However, spring cherimoyas partially develop during winter and need 7 months (Soler et al., 2002). Production of winter cherimoyas needs 5 to 6 months (Table 3). Tentatively, a heat requirement of 2579 growing degree-days (GDD) with a basal temperature of $5^{\circ} \mathrm{C}$ has been established for cherimoya from bloom to harvest using the double-sine method proposed by Zalom et al. (1983). The differences in heat requirements among fruit maturing during different seasons does not exceed 7\% in GDD (L. Soler and J. Cuevas, unpublished).

In summary, our results show the possibility of promoting out-ofseason bloom in cherimoya by eliminating the paradormancy imposed by leaves over the subpetiolar buds. The shoots that were tipped and defoliated formed flowers and large fruit of comparable quality with those obtained in autumn. The yield in treated trees did not differ either with that of control trees $\left(\approx 13 \mathrm{t} \cdot \mathrm{ha}^{-1}\right)$, whereas the distribution of fruit size classes improved (Fig. 4). The tip pruning and defoliation delayed harvesting to the more lucrative months of December and January. The mean fruit value during winter in the main Spanish markets is $\$ 2.6 / \mathrm{kg}$, whereas the price for the main season averages $\$ 1.4 / \mathrm{kg}$ (Empresa Nacional MERCASA, 2006). This work has demonstrated the possibility of producing more profitable cherimoya fruit during the winter in early-season areas.

\section{Literature cited}

Alique, R. and J.P. Zamorano. 2000. Influence of harvest date within the season and cold storage on cherimoya fruit ripening. J. Agr. Food Chem. 48:4209-4216.

Empresa Nacional MERCASA. 2006. Precios y mercados mayoristas. 7 Apr. 2007. <www.mercasa.es/nueva/_html/ 06_productos_sem.php $>$.

George, A.P. and R.J. Nissen. 1987. Effects of cincturing, defoliation and summer pruning on vegetative growth and flowering of custard apple (Annona cherimola $\times$ Annona squamosa) in subtropical Queensland. Austral. J. Expt. Agr. 27:915-918.

González, M., J.J. Hueso, F. Alonso, R. Pérez, and J. Cuevas. 2005. Anticipación de la floración mediante poda temprana y defoliación manual en el cultivar de chirimoyo 'Campas'. Actas Portuguesas Hort. 6:150-155.

Guirado, E., J.M. Hermoso, M.A. Perez de Oteyza, and J.M. Farré. 2004. Introducción al cultivo del chirimoyo. Caja Rural de Granada, Granada, Spain.

Higuchi, H. and N. Utsunomiya. 1999. Floral differentiation and development in cherimoya (Annona cherimola Mill.) under warm $\left(30 / 25^{\circ} \mathrm{C}\right)$ and $\operatorname{cool}(20 / 15$ $\left.{ }^{\circ} \mathrm{C}\right)$ day/night temperatures. J. Jpn. Soc. Hort. Sci. 68:707-716.

Magdahl, C. 1989. Efecto de la defoliación anticipada sobre la brotación, floración y desarrollo de frutos de chirimoyo cv. Concha Lisa y efectividad de algunos productos como defoliantes. Univ. Católica de Valparaíso, Valparaiso, Chile, MS thesis.

Ministerio de Agricultura Pesca y Alimentación. 1990. Norma de calidad para chirimoyas. Ministerio de Agricultura Pesca y Alimentación (MAPA), Madrid, Spain.

Popenoe, W. 1921. The native home of the cherimoya. J. Hered. 12:331-337.

Richardson, A.C. and P.A. Anderson. 1996. Hand pollination effects on the set and development of cherimoya (Annona cherimola) fruit in a humid climate. Sci. Hort. 65:273-281.

Schroeder, C.A. 1941. Hand pollination effects in the cherimoya (Annona cherimola Mill.). Calif. Avocado Soc. Yrbk. 26:94-98.

Soler, L., J. Mateos, and J. Ruiz. 2002. Estrategias para la producción de chirimoyos (Annona cherimola Mill.) en primavera. In: III Intl. Congr. Annonaceae. Quillota-La Serena. Ed. Vlloa, Chile. p. 15 (abstr.).

Thakur, D.R. and R.H. Singh. 1965. Studies on floral biology of annonas. Indian J. Hort. 22:238-253.

Zalom, F.G., P.B. Goodell, L.T. Wilson, W.W. Barnett, and W. Bentley. 1983. Degree-days: The calculation and use of heat units pest management. Lflt. 21373. University of California, Division Agriculture and Natural Resources, Davis, CA. 